\title{
Políticas de la memoria en y desde la imagen. La serie fotográfica Chaco 1978 de Pedro Luis Raota
}

\section{Politics of Memory In and From the Image. The Chaco 1978 Photographic Series by Pedro Luis Raota}

\author{
Mariana Giordano, Alejandra Reyero y Luciana Sudar Klappenbach \\ CONICET-UNNE / CONICET-UNNE / FADYCC-UNNE. Chaco, Argentina. \\ marianalgiordano@gmail.com / reyeroalejandra@gmail.com / lu_sudar@hotmail.com
}

\section{Resumen}

Este trabajo analiza la serie de fotografías Chaco 1978 de Pedro Luis Raota, como parte de la práctica fotográfica de la última dictadura militar en la Argentina. Se entiende a las imágenes de la serie como agentes de un proyecto político-visual de construcción/ presentación de la provincia del Chaco en el contexto propagandístico nacional y provincial. Se exploran las vinculaciones entre la producción fotográfica del autor y el discurso y la ideología de la última dictadura militar argentina, con la finalidad de desmontar las estrategias de producción y circulación de la serie a efectos de repensar el eslogan "Chaco puede", establecido desde el gobierno provincial, en consonancia con la política nacional de "refundar la Nación".

Palabras clave: fotografía, Raota, dictadura militar, memoria, imaginario.

\begin{abstract}
This paper analyzes the photographic series Chaco 1978 by Pedro Luis Raota, as part of the photographic practice during the last military dictatorship in Argentina. The images of the series are understood as agents of a visual policy project of construction / presentation of the province of Chaco in both the national and provincial propaganda context. The linkages between the photographic production of Raota and the discourse and ideology of the last Argentine military dictatorship are explored, with the purpose of dismantling the production and circulation strategies of the series. That in turn allows us to rethink the "Chaco can" slogan established by the Provincial Government and its relationship with the national policy of "Refounding the Nation."
\end{abstract}

Keywords: photography, Raota, military dictatorship, memory, imaginary. 


\section{Introducción}

La serie de fotografías Chaco 1978 de Pedro Luis Raota surge en el marco de un proyecto político-visual de presentación de la provincia del $\mathrm{Chaco}^{1}$ en el contexto de la última dictadura militar argentina. En tal sentido, es testimonio de las relaciones directas entre el fotógrafo, el gobierno provincial y nacional, ya que sus imágenes responden a un encargo explícito por parte de los funcionarios de la época y guardan relación con el eslogan propagandístico "Chaco puede”. Este lema/ imperativo ideológico había sido deliberadamente elegido por la dirigencia local en consonancia con la política nacional de "refundar la Nación” y las imágenes de Raota lo respaldan visualmente.

Aunque las fotos fueron presentadas como respuesta a la necesidad personal de Raota de "reencontrarse con su tierra natal", se convierten en vehículos de poder (visual, político-cultural y social). Trascienden la propia individualidad subjetiva y la "inocente" intencionalidad del autor y forman parte de una clara estrategia institucional-estatal de construcción de memorias hegemónicas que nos impide analizarlas desde una noción exclusiva de autorreferencialidad. Evitando así el riesgo de su estetización excesiva, las consideramos -siguiendo a Longoni- desde su rol y función en un régimen visual marcado por el cruce entre estética y política, historia y memoria.

Estas imágenes constituyeron una política de memoria en y desde lo visual: una memoria compacta y unívoca en una provincia de gran diversidad étnica, que, a pesar de ser una de las más pobres del país, con grandes desigualdades sociales, ${ }^{2}$ se presenta desde el imaginario nacional como "ejemplo de progreso".

La circulación de las fotos en distintas localidades del interior provincial y su constitución en patrimonio artístico del Banco del Chaco respondieron a una política cultural de difusión y legitimación del Estado provincial. En tal sentido, si bien abordamos la producción de Raota en un espacio acotado -la provincia del Chaco-, su lectura global debe entenderse en el contexto nacional del programa ideológico del gobierno militar argentino. En consecuencia, aun cuando su referente no remita a las atrocidades vividas durante ese periodo, son imágenes obtenidas en un contexto de violencia institucional nacional, cuyo autor ese mismo año había actuado como fotógrafo oficial del Mundial de fútbol realizado en el país. Estas imágenes, en su

1 Parte de la región del Gran Chaco Americano, la provincia del Chaco está ubicada en el nordeste argentino, constituida como tal en 1951, siendo previamente incorporada a la administración nacional como Territorio Nacional (1872), cuando el Estado argentino avanzó sobre la región del Chaco argentino con paulatinas entradas, creación de colonias de inmigrantes y campañas militares contra los grupos indígenas que ocupaban la región. Como consecuencia de esas campañas, finalizadas entre 1911 y 1912, se produjo la sedentarización de los grupos cacicales, su inclusión en reducciones o colonias agrícolas, o su dispersión hacia regiones periféricas, existiendo en la actualidad tres grupos étnicos: qom (Toba), moqoit (Mocoví) y wichi (Mataco).

2 Por mencionar algunos indicadores, en 1980 el Chaco tenía el índice más alto de analfabetismo en la Argentina: $17,7 \%$ sobre una media nacional de $6,1 \%$ (INDEC, Censo Nacional). Ese mismo año, la mortalidad infantil ascendía al 54,2\% nacidos vivos, sobre un promedio país de 33,2\%o (INDEC, “Tasa de mortalidad”). 
conjunto, pretendían poner un manto de "normalidad y bienestar" en medio de una sociedad signada por el horror. ${ }^{3}$

Atendiendo al entramado político, social y artístico de producción de estas imágenes, adoptamos desde el punto de vista teórico-metodológico perspectivas analíticas interdisciplinares provenientes de los estudios visuales que aluden a la construcción visual de lo social (Mitchell), el poder de las fotografías en el entramado institucional (Tagg) y la necesidad de considerar fuerzas externas al universo visual (Sekula cit. en Batchen). Se incluyen a su vez los aportes de los estudios culturales -rol ideológico de las representaciones- y los estudios críticos sobre la memoria y el olvido (Jelin; Halbwachs) y perspectivas de la historia reciente. ${ }^{4}$

\section{Raota, su trayectoria fotográfica y el Chaco}

Pedro Luis Raota es un fotógrafo paradigmático en la Argentina, cuya producción y actuación "divide aguas" entre historiadores, críticos y fotógrafos. Nacido en el Chaco en 1934, se trasladó de joven a la localidad de Villaguay (Entre Ríos) para realizar el servicio militar obligatorio y fue allí donde se inició en la fotografía, convirtiéndose en fotógrafo comercial, a la vez que se relacionó con los ámbitos fotoclubistas, comenzando a recibir premios nacionales e internacionales desde $1970 .{ }^{5}$ Sara Facio ubica a Raota dentro de los fotógrafos argentinos fotoclubistas y expositores en Salones, promotor de una temática "ingenua, ilustrativa, previsible, y aquellos títulos elementales [...] que producen impacto en el público y los medios” (49). A la vez, esta fotógrafa distingue a Raota del resto de los fotoclubistas por la calidad de las tomas y el manejo de técnicas más avanzadas, tanto en los equipos utilizados como en las copias realizadas. ${ }^{6}$ Estos rasgos generales que Facio identifica en la producción de

3 Son numerosos los textos que han abordado las imágenes del horror en la última dictadura cívico militar argentina, tanto en imágenes producidas en ese contexto como en producciones posdictadura que remiten a la "memoria sobreviviente”. Entre ellas, cabe señalar Feld; Blejmar, Fortuny y García; Da Silva Catela; Lorenzano y Buchenhorst; Larralde Armas; Gamarnik (ver tres obras en Referencias); Triquell.

4 Cabe señalar que, si bien en la Argentina los estudios de historia reciente -y en particular los vinculados a la última dictadura militar- tienen una actualidad y producción significativa (Franco y Levín; Jensen y Águila, entre otros), en el ámbito de la historiografía del Chaco hay una falencia en este campo disciplinar.

5 La información biográfica de este fotógrafo se repite en diversos catálogos y fuentes bibliográficas, y es la que se encuentra incluso en la página web de su hijo, José Luis Raota, www.raota.com.

6 Esta afirmación de Facio vinculada a las expectativas de un público masivo respecto de la fotografía fotoclubista deja abierta varias cuestiones a considerar: por un lado, el carácter de las producciones fotográficas de las décadas del sesenta y setenta en Argentina que no se limitaron a las características señaladas, pero tuvieron una fuerte impronta nacionalista, sesgo fotográfico que era canalizado a un gran público, no solo por el Estado, sino por los mismos fotógrafos mediante la venta de sus portafolios y su participación en revistas o diarios de difusión masiva. Por otro lado, esto lleva también a considerar otros gustos y usos de la fotografía en la época: mientras algunos fotógrafos se orientaban a la fotografía fotoclubista, otros se enfocaron en la práctica artística (Heinrich) y en el ensayo fotográfico (Stern, en su serie Aborígenes del Gran Chaco). Pero también hubo quienes desde el fotoperiodismo trataron los sucesos político-sociales de la última dictadura militar en la Argentina (Daniel García, Guillermo Loiácono, Carlos Villoldo, Mario Fiordelisi, Eduardo Longoni, entre otros), muchos de ellos nucleados en el "Grupo de Reporteros Gráficos", forma en que se presentaron colectivamente ante el contexto político. 
Raota, como también su vinculación a las demandas de imágenes para las campañas oficiales de la dictadura, constituyen el contexto de producción de la serie que aquí analizamos: las imágenes del Chaco de 1978. En efecto, fueron este tipo de imágenes las que le permitieron obtener numerosos premios internacionales y una notoria presencia en eventos cercanos al poder militar argentino, entre 1978 y 1982.

En 1978, radicado en Buenos Aires, Raota regresa transitoriamente a su tierra natal, en el contexto de un gobierno militar provincial liderado por la intervención del general Facundo Serrano, quien pretendió exhibir a la provincia en el contexto nacional como un polo de desarrollo regional, un ámbito donde el "progreso" era posible. Uno de los hitos de esa gestión fue la expansión al Impenetrable chaqueño con la fundación de Fuerte Esperanza en 1978, símbolo de la "avanzada civilizatoria", reconocida en el discurso oficial - del que se hizo eco el periodístico-, como la "segunda colonización del Chaco". 8

La propaganda oficial de la época respecto de esta "expansión-colonización”, pone en evidencia los presupuestos ideológicos del gobierno militar provincial consecuentes con la política nacional:

Nace Fuerte Esperanza porque renace el país. Vuelve a asomarse a la faz de la tierra una nueva y gloriosa Nación: nuestra Nación, nuestra nueva Argentina. La Argentina que hoy funda Fuerte Esperanza, enclavándolo en la inmensidad verde de El Impenetrable Chaqueño. Porque Fuerte Esperanza proclama la voluntad argentina de conquistar cuatro millones de hectáreas de monte chaqueño para alimentar el espíritu de grandeza de nuestro pueblo y para paliar el hambre mundial. Fuerte Esperanza proclama además la ambición de revigorizar el Gran Chaco, como estratégica zona geopolítica de América Latina. Antaño cada fuerte que se enclavó en nuestra patria identificó a una avanzada colonizadora. Avanzadas civiles y militares que llevaron cultura, trabajo y seguridad a lo largo y a lo ancho del país. Avanzadas que traducían la adaptación de los argentinos a un mundo que cambiaba, en el que América comenzaba a ser la tierra prometida. Fuerte Esperanza es una nueva avanzada colonizadora argentina (El Territorio, 23 sep. 1978, p. 2).

1978 era a su vez el año en que se conmemoraba el centenario de la fundación de la ciudad capital del Chaco, Resistencia, con el arribo del primer contingente de in-

7 Fuerte Esperanza es una localidad creada en el Chaco (departamento General Güemes, región del Impenetrable chaqueño), con el propósito explícito de propiciar la ocupación y el control de los territorios y frontera norte, a la vez de extender la frontera agropecuaria y forestal. Esta avanzada es conocida como la "Campaña del Oeste" y constituye una segunda colonización del Chaco. La inauguración de Fuerte Esperanza el 22 de septiembre de 1978 contó con la presencia del presidente de facto Jorge Rafael Videla. El nombre elegido para la localidad sintetiza los ideales de la dictadura: recupera la idea del fuerte militar y lo articula con un concepto repetido en la propaganda gubernamental: "esperanza".

8 En la trama discursiva que legitimaba la construcción de memorias, la "primera colonización" había sido la llegada de inmigrantes italianos a Resistencia en 1878. 


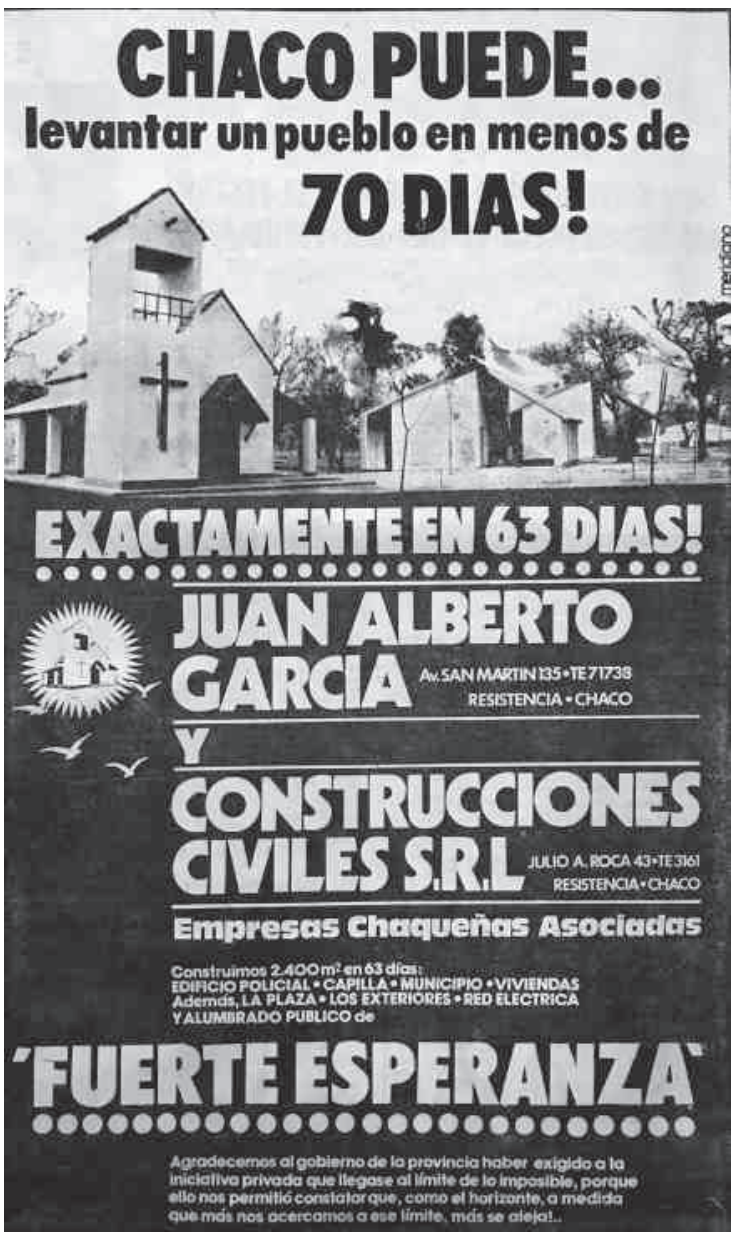

Aviso periodístico sobre la "fundación" de Fuerte Esperanza, que incorpora el eslogan "Chaco puede". Fuente: El Territorio, 23 sep. 1978.

migrantes italianos. ${ }^{9}$ Fue precisamente esta "gesta inmigratoria", que en el siglo XIX se había convertido en un hito del poblamiento y la consolidación de la soberanía nacional del entonces Territorio Nacional del Chaco, la que permitió que el Estado nacional continuara con los avances militares y el sometimiento del indígena. A cien años de aquel hecho, las construcciones estatales, la extensión de líneas eléctricas y los monumentos conmemorativos se volvieron algunas de las marcas simbólicas y construcciones memoriales que operaron de marco propagandístico del gobierno militar en un ambiente de festejos y celebraciones. Y la fundación de "Fuerte Esperanza", como ya se hizo referencia, fue uno de los íconos clave de esta nueva colonización (fig. 1). 
En este contexto, Raota fue convocado por funcionarios técnicos del Banco del Chaco -entidad oficial de la provincia-, para realizar las imágenes que sintetizaran el Chaco contemporáneo. Al asumir el gobierno militar en 1976, tal como afirma Carlino, la provincia del Chaco sostenía una década de crisis estructural y la banca pública acusaba grandes dificultades financieras. Se produjo la intervención del Banco del Chaco y luego la conformación de un staff técnico con personalidades procedentes de Buenos Aires. ${ }^{10}$

Fue en el marco de una entidad pública dirigida por ejecutivos ajenos a la provincia, que Raota recibió la propuesta de realizar un reportaje fotográfico en/sobre el Chaco. Estas imágenes acrecentaron la pinacoteca del banco que esta gestión comenzó a constituir. La misma incluía principalmente la adquisición de pinturas -aunque también se incorporaron grabados, dibujos y esculturas- de importantes artistas argentinos como Quinquela Martín, Soldi, Thibon de Libian, Presas, Castagnino, Butler, entre otros. La producción de Raota fue la única obra fotográfica que integró esta pinacoteca, que hoy se encuentra en el Museo Provincial de Bellas Artes "René Brusau" de la ciudad de Resistencia. ${ }^{11}$

Si bien no se han encontrado documentos contractuales entre el banco y el fotógrafo -los archivos del banco de esa época han desaparecido en gran parte-, no pareciera haber existido condiciones específicas sobre los temas/objetos de sus tomas, conforme a las entrevistas realizadas a empleados del mismo en el marco de este trabajo. ${ }^{12}$

Al arribar Raota al Chaco, el banco le proveyó de movilidad y dos empleados, de apellidos Lindstrom y Maidana, que lo acompañaron en el itinerario por el interior de la provincia. ${ }^{13}$ Incluso realizó algunos trayectos en el avión del banco, lo que le posibilitó tomas aéreas. ${ }^{14}$ En función de las imágenes realizadas en la ciudad de Resistencia referidas a grandes edificaciones en construcción -Domo del Centenario y Banco del Chaco- y por el registro de la Fiesta del Inmigrante que se realiza anualmente en Las Breñas en los meses de septiembre-octubre, y considerando a su vez que sus fotos se expusieron públicamente en septiembre de 1978, suponemos que el fotógrafo recorrió el Chaco en los últimos meses posteriores al Mundial de fútbol realizado en Argentina (1 al 25 de junio de 1978), evento del que Raota fue uno de los reporteros gráficos oficiales.

10 La presencia como presidente de Miguel Emilio Perés, estuvo acompañada por un consejo asesor integrado por Amílcar Urrutia, Ginés Sáez y Rodolfo Durañona (Carlino 132-133).

11 Cabe señalar que, en 1978, momento en que se produjo la serie Chaco, la provincia del Chaco no poseía un museo de Bellas Artes, que recién fue creado por Decreto n. ${ }^{\circ} 1176$ en 1982 y abrió sus puertas en 1984. La pinacoteca del Banco del Chaco -en la que se inserta esta serie de Raota y un álbum de muestras de las imágenes- estuvo durante mucho tiempo en guarda en el Museo Provincial de Bellas Artes "René Brusau". Las imágenes de Raota fueron expuestas en diversas muestras del patrimonio del museo; asimismo, copias de algunas de ellas que se le encargaron al mismo Raota, decoraron diversas oficinas de reparticiones estatales durante todos los gobiernos democráticos que se sucedieron.

12 En particular, la información provista por Ricardo Daneri, jefe del Departamento de Patrimonio del banco en 2007 cuando se realizó la entrevista y empleado del mismo en la época en que Raota realizó su trabajo para el banco.

13 Entrevista a Ricardo Daneri. Resistencia, 21 de febrero de 2007.

14 Las imágenes Urgente y Así se construyó la Patria son una muestra de este tipo de tomas. 
FIGURA 2

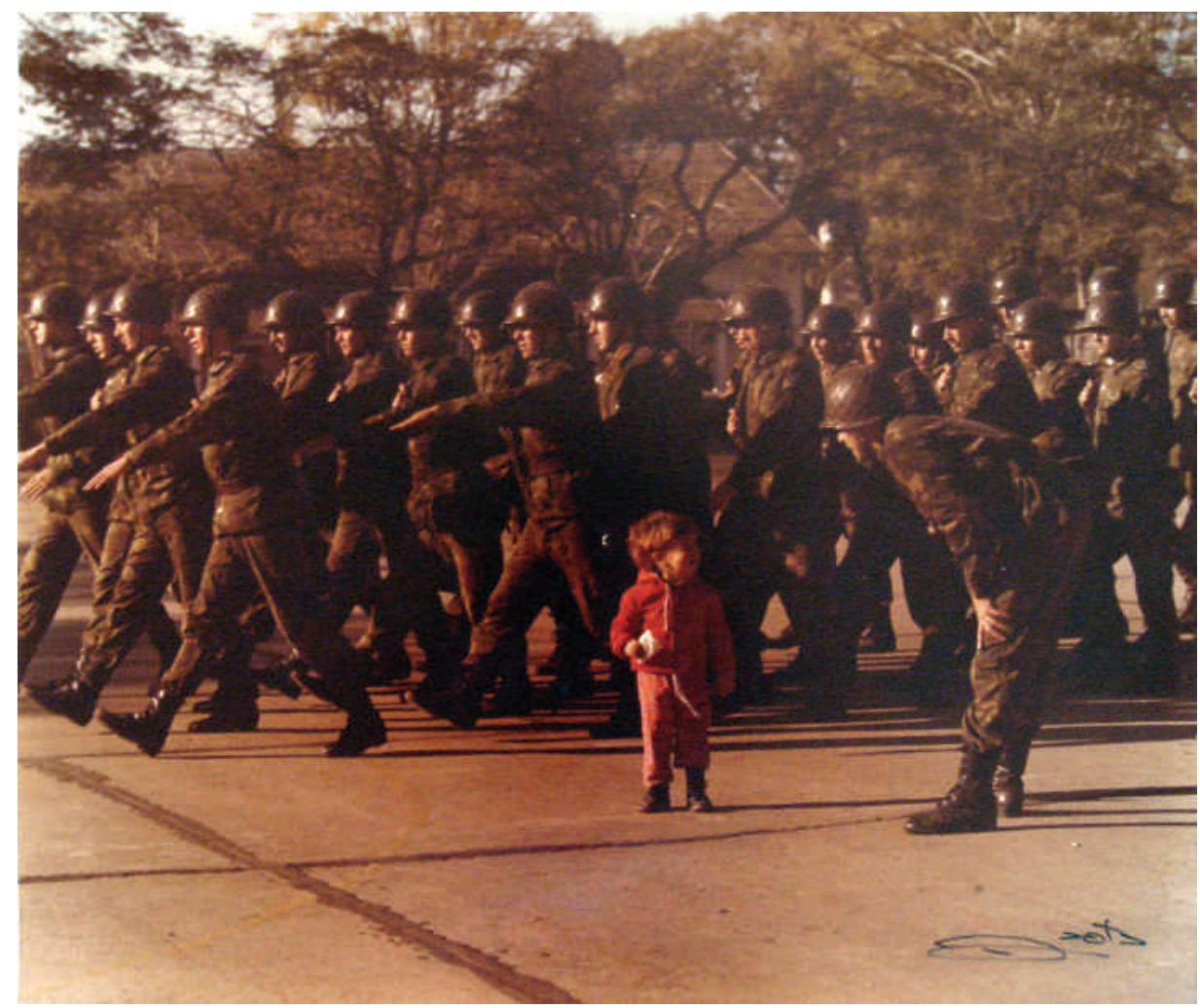

Pedro Luis Raota. Acto de servicio (1978). Museo Provincial de Bellas Artes "René Brusau”.

La inauguración del Domo del Centenario, edificio paradigmático del proceso militar en la ciudad de Resistencia, capital del Chaco, se realizó en el mismo día de la inauguración oficial de Fuerte Esperanza, el 22 de septiembre de 1978. Ambos eventos fueron presididos por el presidente de facto Jorge Rafael Videla y fue el Domo el ámbito donde por primera vez se realizó una exposición de las fotografías de Raota. La prensa local reflejaba este hecho, comentando algunas de las fotografías de la exposición que sintetizaban el nacionalismo militar de la época, entre ellas Acto de servicio (fig. 2), y reproducía imágenes de parte de la serie en el contexto de la visita presidencial. Asimismo, las notas periodísticas relataron el obsequio que el presidente del Banco del Chaco, Miguel Perés, otorgó al mandatario nacional: “[...] el presidente del directorio del Banco del Chaco le obsequió un trabajo de Raota, que el jefe del Estado recibió con verdadero beneplácito ya que se trataba de un atardecer chaqueño en incendio, donde se observaba a dos agricultores con herramientas de labranza que regresaban a sus hogares concluida la jornada" (El Territorio, 23 sep. 1978, p. 2). 
Por lo que se deduce de la prensa, Raota no estuvo presente en este acto inaugural del Domo del Centenario. La exposición de la serie Chaco 1978 se presentó como el evento artístico en el contexto de las inauguraciones edilicias mencionadas previamente y la refacción del parque "2 de febrero", entre otros de la capital chaqueña. Es decir, las imágenes que se seleccionaron especialmente para ser expuestas fueron elegidas por su poder de representar visualmente los ideales sociopolíticos del momento que atravesaba el país. Es en función de tales ideales que aquellas imágenes -las elegidas para formar parte de la exposición- resultaron significativas, cobraron determinado valor y sentido según el marco en el cual fueron exhibidas y es por ello que hoy resultan de interés para el análisis aquí planteado.

En tal sentido, y acorde a los objetivos de este trabajo, podemos decir -siguiendo a Burgin- que el objeto de análisis no es solo la propia imagen, sino también las prácticas de significación que la preceden, rodean, condicionan y convierten a cada fotografía en significativa.

La serie está conformada por 141 copias color de 50 x 60 centímetros y un álbum de 85 copias blanco y negro. De muchas de estas imágenes el propio Raota realizó copias que fueron expuestas en diversos ámbitos estatales. ${ }^{15}$

\section{Tópicos de representación y construcción visual del "Chaco puede"}

Producción, expansión, crecimiento, patrimonio, trabajo y progreso fueron algunos de los conceptos utilizados por la propaganda pública del gobierno de facto argentino durante la dictadura de 1976-1983, ${ }^{16}$ y serán los que la estética de Raota buscará visibilizar. La evocación de espacios, lugares y contextos sociales ideales se corresponden a la vez con una "limpieza" de la imagen que se complementa con títulos alegóricos, inocentes o "elementales" (Facio 49) que restringen los sentidos posibles. Así, el Chaco es preconcebido según tópicos que Raota ya eligió representar con relación a otros contextos socioculturales. Es decir, que en este como en los otros casos, la imagen está precedida por un concepto acerca de cómo construir visualmente lo social (Mitchell). Pero, a la vez, la fotografía "como tecnología [que] varía con las relaciones de poder que la impregnan. Su naturaleza como práctica [que] depende de las instituciones y de los agentes que la definen y la ponen en marcha, es capaz de cobrar sentidos distintos según el contexto -momento y lugar circunstancial- en que se difunda, aunque los mecanismos de producción se asemejen en cada oportunidad" (Tagg 85). Es en ese entramado que estas imágenes

\footnotetext{
15 Sobre la cantidad de imágenes originales -y las faltantes-, las copias realizadas y su destino, como así también las características técnicas y el estado de conservación de la colección, véase Giordano y Sudar Klappenbach (45-46). 16 Sobre la prensa en la última dictadura argentina, véase Saborido y Borelli; Poggio, entre otros.
} 
se convierten también en elementos de poder, que construyen visualmente un mundo social chaqueño por parte del Estado, que difunde estas imágenes como representativas del Chaco. ${ }^{17}$

En este sentido, Raota señala en su primer libro editado en 1976 ciertas ideas acerca de su práctica artística, las cuales actúan de preludio a la producción del Chaco dos años más tarde:

[...] podré mostrar lo que recoge mi cámara a través de tantas sensaciones vividas en muchos caminos, en mil rostros, en distintas razas, pero fundamentalmente de todas esas cosas de todos los días, de todos los seres, que no hacen a la geografía sino al sentir común de todos los hombres de la tierra, desde el que se inclina sobre un arado, el que trepa en el andamio, el que corre a una oficina o el que decide el destino de una nación... (Raota s. p.).

Esa mirada "humanitaria y cosmopolita" que Raota pretendía plasmar en sus imágenes se advierte en la producción fotográfica chaqueña, donde las composiciones parecieran reinventarse/actualizarse/resignificarse siempre con un mismo concepto de "lo fotografiable".

Un recorrido visual por las imágenes que componen la serie revela un imaginario homogéneo sosteniendo un mismo hilo argumentativo. Esta producción resume aquellos aspectos que resultaron primordiales para la (re)construcción de una identidad nacional a partir de una región periférica. Las escenas construidas pueden ser categorizadas bajo ejes temáticos como educación, salud, trabajo, obras públicas, paisajes naturales y construidos, lo cotidiano, la gesta inmigratoria, el hogar, la familia. Un esencialismo visual y social unifica estas categorizaciones.

\section{Retrato, familia, fiesta: un ideario social}

El retrato de primer plano, de medio cuerpo o cuerpo entero, individual y grupal, es abordado por Raota como modo de conformación de un colectivo social y no como referente de una identidad individual. Si bien todo retrato es un sistema convencional de representación, una forma simbólica (Burke 133), en Raota el interés no está en el (los) sujeto(s) representado(s), sino en tanto integren(n) un colectivo social al que pretende poner de relieve como parte de una sociedad cohesionada. Como señala Poggio, “[...] el Gobierno militar apela a la exaltación de lo nacional como valor para crear la cohesión social y al miedo más primigenio a la destrucción del cuerpo (social) para legitimar las acciones gubernamentales vinculadas al Terrorismo de Estado" (1383).

17 Si bien señalamos que la serie Chaco 1978 fue expuesta en 1978 en Resistencia, luego comenzó una itinerancia por diferentes poblados del interior chaqueño. 
Recordemos que el término "caos" había sido uno de los más utilizados en la prensa durante 1975 y su uso abusivo fue un elemento más de posibilidad del golpe. En tal sentido, la imagen de un universo social cohesionado, estable, sin conflicto, contradecía en el imaginario a aquella imagen del caos que desde diversos medios políticos y periodísticos se había difundido.

Muchas son las imágenes en las que el fotógrafo registra el rostro de un niño o una niña, un(a) anciano(a), una pareja de cónyuges o a una familia entera; ellas siguen esquemas muy precisos de poses, gestos y actitudes que en su conjunto simbolizan también roles sociales como la familia, el matrimonio, la salud y la educación de los niños en el hogar, el trabajo doméstico. Todos estos conceptos podrían entenderse como prácticas socioculturales de la vida cotidiana rural del Chaco, pero son, sin embargo, representaciones estereotipadas que se repiten en la iconografía de distintos gobiernos dictatoriales: siempre se alude a sujetos "sencillos" con aspiraciones satisfechas o con necesidades cubiertas por el Estado. En su mayoría vinculados al ámbito rural, tienen una vida apacible y festiva, como en Gringa chaqueña, La casa del gringo o Gringo en la feria (fig. 3). ${ }^{18}$ En su conjunto, estas representaciones de sujetos, familias $\mathrm{y}$ actores sociales aluden a una sociedad con una fortaleza, un "nosotros" compacto que se opone al "enemigo" de una "Nación enferma" (Borelli y Saborido 54) que se encuentra invisible en la serie: ese enemigo que simbolizaba el "peligro subversivo" en el discurso de la dictadura y que se contrapone explícitamente a la imagen de una sociedad pacífica y cohesionada propuesta por Raota.

Las imágenes sociales de Raota representan la experiencia vital en tanto símbolos de un ideal. Las circunstancias habituales y corrientes que nos muestran algunas ya referidas como Gringo en la feria, o aquellas situaciones y actividades recreativas, Fiesta y Fiesta en Las Breñas, ${ }^{19}$ son (re)presentadas como grandes escenografías (fig. 4). Detalles de vestimenta y mobiliario sitúan la escena fotografiada en el mundo de pequeñas poblaciones o en el ámbito rural. Los sujetos aparecen como defensores de la tradición nacional, representados bajo un ideal de "sociedad organizada" (en paz y libertad) omitiendo cualquier elemento de conflicto. Subyace en cada una de estas fotos una suerte de nostalgia y reivindicación de una "aldea tradicional" claramente graficada en el modo de vida del campesino y sus ocupaciones diarias. El gringo y La gringa chaqueña devienen -después de haber atravesado un proceso de idealizaciónexpresiones visuales de una idea de sociedad en la que los pueblos indígenas del Chaco quedaban excluidos, tal como veremos más adelante. "El rostro del otro no aparece plenamente, pues su significación es, en realidad, ética” (Leconte 29).

Los retratos infantiles ocupan un lugar destacado en la serie Chaco 1978; la mayoría de ellos tienden a afianzar la ingenuidad e inocencia tan cara a la poética de Raota, que

18 Cabe señalar que en el Chaco se denomina "gringo" al inmigrante europeo.

19 Esta última representa al grupo de inmigrantes españoles, conocidos como los "gaiteros breñenses". El registro que Raota hace de la fiesta del inmigrante en su tercera versión, reafirma el ideario de la gesta inmigratoria, muy vigente en este contexto político, social y cultural. 
FIGURA 3

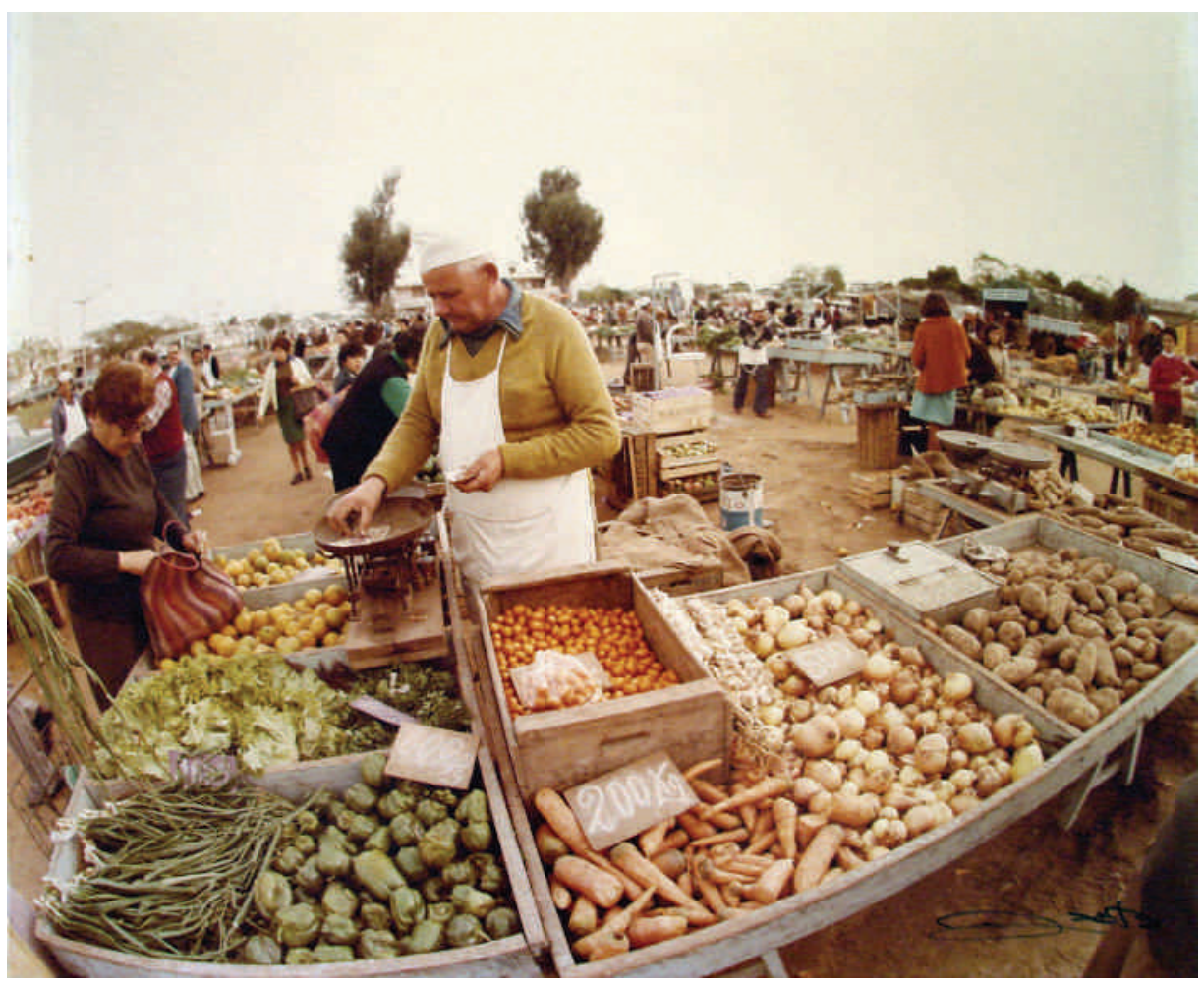

Pedro Luis Raota. Gringo en la feria (1978). Museo Provincial de Bellas Artes "René Brusau”.

se enfatiza en los títulos de las fotos. Imágenes como Mamá no viene, El precio de la salud o Viento norte, podrían ser los únicos pliegues de este imaginario progresista por tratar el tema de la soledad, la enfermedad y la sequía, pero sin embargo se presentan personajes estoicos que están contenidos por el Estado. Lejos de una exploración de la subjetividad, se apela a la conmoción de sujetos a los que el Estado puede asistir en esta "refundación de la Nación" que propugnaba el discurso militar. En estas tres imágenes el contexto de la toma es una sala o un centro de salud. "El Estado protege" es el mensaje a transmitir y para enfatizar este concepto recurre a imágenes en las que los espectadores puedan verse reflejados, puedan sentir empatía y se identifiquen con el sujeto representado. Conmover, causar sensación en la masa y lograr su convencimiento y devoción. Esta era otra premisa general que parecía guiar las acciones del gobierno de facto y que Raota supo reivindicar en sus fotografías. Sus retratos infantiles son un claro ejemplo de ello gracias a la vulnerabilidad que suponen los niños. ${ }^{20}$

20 La historia social y cultural -entre otras- se ha ocupado de estudiar las imágenes fotográficas de niños, revelando la capacidad de estas para documentar la historia de la infancia o los cambios que la visión de los adultos ha tenido sobre los niños, así como los cambios que estos han experimentado en distintas épocas de distintas sociedades (Burke 134). 


\section{FIGURA 4}

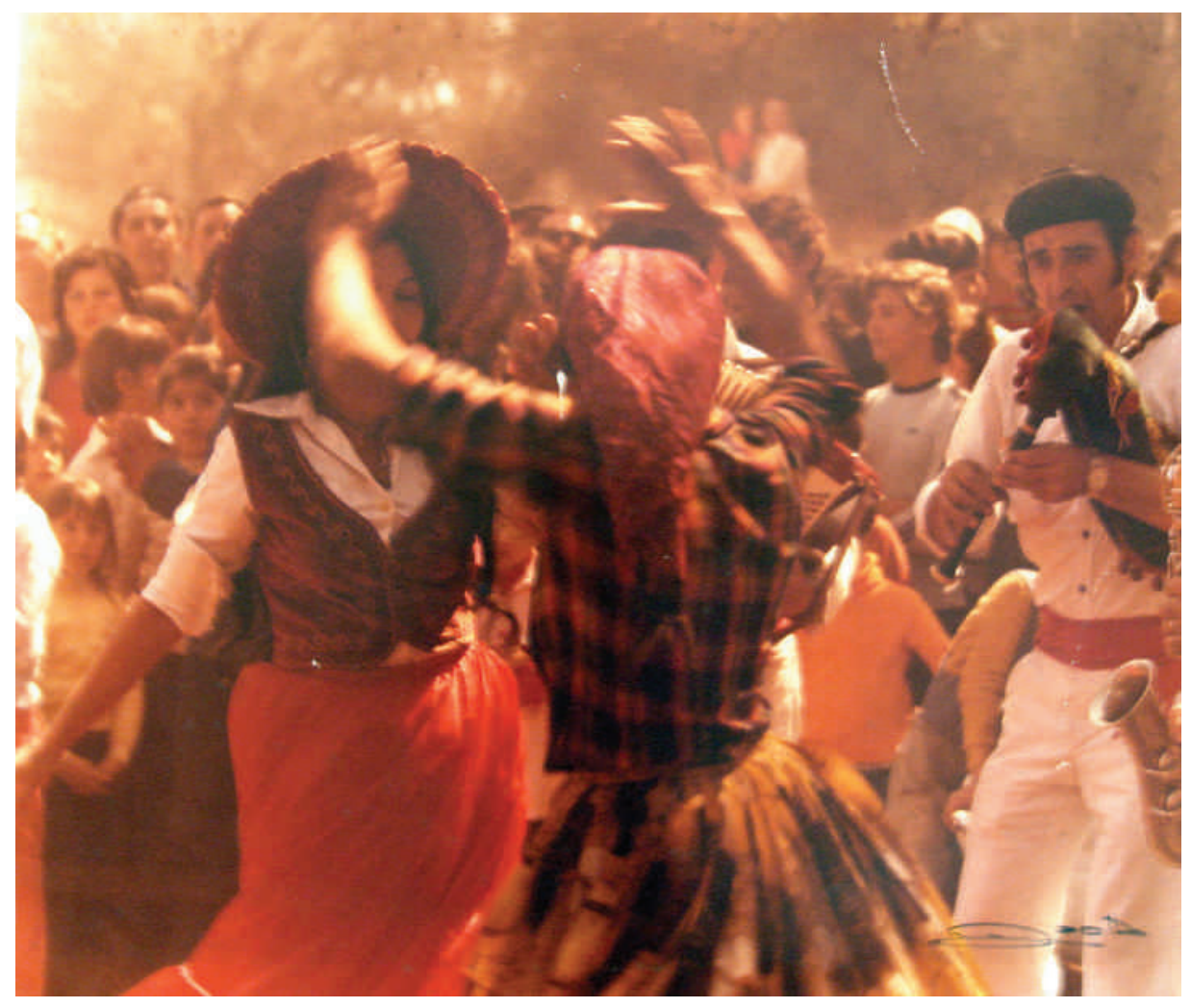

Pedro Luis Raota. Fiesta en Las Breñas (1978). Museo Provincial de Bellas Artes “René Brusau”.

El hogar es también un concepto fuertemente enlazado al ideal de familia que la dictadura militar promovía: "patria” y "familia" fueron los pilares del "acervo cultural" propugnados por la propaganda oficial entre 1976 y 1983. Es en relación con esta idea de hogar que aparece la mayoría de las figuras femeninas, algunas de ellas asociadas a la fe, como en la imagen que lleva ese nombre ( $F e$, El pan nuestro de cada día, Gringa chaqueña, Mi ranchito, Llueve). Los roles asignados a la mujer y los espacios en los que estos debían cumplirse están claramente referenciados en la serie: cocinar, cuidar a los niños, acompañar al marido, rezar, etcétera.

Así, estas imágenes constituyen -parafraseando a Burke- una opinión fotografiada, una visión de la sociedad en un sentido ideológicamente visual. El estereotipo del inmigrante deviene el sello de esta producción. Es cierto que el inmigrante es un factor social influyente en la construcción multiétnica del Chaco; sin embargo, Raota exagera ciertos caracteres del inmigrante, enfatiza repetidamente su presencia progresista, a la vez que silencia e invisibiliza otros sujetos sociales, como veremos más adelante. 
El discurso monolítico de la sociedad chaqueña como resultado de la "gesta inmigratoria" encuentra en esta serie los ejemplos más logrados. ${ }^{21}$ La misma no admite pliegues representacionales, el ideario social apunta a una vida "armoniosa", aun en la pobreza, "laboriosa", aun en medio de dificultades climáticas o contextos naturales adversos, pero cuyo "sacrificio" llevará al "progreso". Una sociedad que puede disfrutar de la vida y por ello la fiesta será central en este imaginario. En definitiva, una sociedad "libre" que disfruta de la vida, cuando en el mismo momento existían miles de desaparecidos, censura y quema de libros y el Chaco ya había vivido, en los inicios de la dictadura, la Masacre de Margarita Belén. ${ }^{22}$

Por lo tanto, Raota representa una propaganda visual del régimen que se articula con los conceptos sobre la sociedad, la tradición y el progreso que expresara el mismo presidente de facto Videla en mayo de 1976:

Decíamos ayer que ésta es la hora de la verdad. La verdad no siempre es simpática; a veces resulta dolorosa. Por eso podemos decir hoy que es también la hora del sacrificio, porque no se concibe progreso sin esfuerzo; y así lo establece el precepto bíblico que dice: "Ganarás el pan de cada día con el sudor de tu frente". Es nuestro deseo que sea también ésta la hora de la esperanza; de una esperanza inspirada en la fe: fe en los valores tradicionales que hacen a la esencia del ser nacional, fe en nuestra potencialidad como Nación, fe en el hombre argentino (Videla 47).

\section{Costumbres y cotidianeidad}

Otro de los ejes de representación propuesto por Raota se refiere a las costumbres urbanas y rurales, a la cotidianeidad de la vida lugareña como elemento de cohesión social. En ocasiones con intención de convertirse en instantáneas, pero sujetas a una sutil construcción de escenas, imágenes como La verdulera o Reunión de amigos se convierten en prototipos de estas estampas de la vida chaqueña.

En La verdulera, un ambiente interior de una vivienda humilde alberga a personajes que no parecieran tener relación familiar, sino participar de un contexto de referencia sociocultural: un hombre con el acordeón en mano -la "verdulera"- observado intrigantemente por una niña, junto a una mujer anciana que está dando la mamadera a un bebé y un joven policía en un segundo plano. En su conjunto estos personajes se contraponen formalmente a un joven sentado en actitud casi ascética. El símbolo de unión de todos los sujetos es la "verdulera”. Esta escena condensa los

21 No es casual que en el mismo año en que Raota realiza esta serie, se inaugura en la ciudad de Resistencia el Monumento al Inmigrante, realizado por el artista Eddie Torre, cuyo perfil ha pasado a constituir el logo que caracteriza desde entonces al Municipio de Resistencia.

22 En la noche del 12 al 13 de diciembre de 1976 se produjo la ejecución de 22 presos políticos -previa tortura-, realizada en un operativo conjunto del Ejército Argentino y la Policía del Chaco en un sitio cercano a la localidad de Margarita Belén, provincia del Chaco. 
estereotipos sociales y los valores propugnados por el modelo ideológico vigente: experiencia, juventud, niñez (esperanza y futuro), música y milicia. Tanto en esta como en otras imágenes la pobreza se vislumbra, pero siempre de modo pintoresco y hasta "romántico". Si el contexto es de pobreza, esta es apenas un resabio del pasado que el nuevo régimen de conducción política logrará desterrar. Reunión de amigos es otra imagen que también ejemplifica algunos de estos presupuestos.

Se trate de acciones o situaciones festivas (singulares), como habituales y corrientes, las imágenes sociales de Raota -en especial aquellas de temática familiar-construyen visualmente formas de comportamiento social: tomar mate, asar el lechón, asistir al médico, a la feria, el traslado en carro o auto a la ciudad, entre otras acciones que en su generalidad aluden a un costumbrismo narrativo que en el contexto del discurso de la dictadura pueden ser entendidas como elementos del "salvataje" de la nación. Gran parte de la serie se refiere a esas escenas de "su tierra natal" prefiguradas por medio de la experiencia de viaje del fotógrafo por algunos espacios del interior chaqueño. Lo racional y simbólico se cruza con lo emocional y sensible en imágenes cargadas de fuerte color local.

Estas imágenes de la cohesión social constituyen la contracara de una producción fotográfica que se realizaba en la misma época y que, por el contrario, piensa visualmente la dictadura desde la escisión, el conflicto y la represión, desde la cobertura pública de las manifestaciones, aunque muchas veces ello implicaba "sacar fotos para guardarlas y no mostrarlas..." (Gamarnik, "La fotografía irónica” 71), atendiendo a la distinción entre lo fotografiable y lo mostrable en ese contexto.

\section{Rostros y culturas ausentes}

Como expresamos previamente, las construcciones estereotipadas del sujeto chaqueño son monolíticas en la serie. Pero a ellas se suman prácticas de omisión concretas, en especial en relación con la figura del indígena, que está invisibilizada, aunque aparece en otras producciones del fotógrafo. ${ }^{23}$

Indudablemente, al recorrer el Chaco Raota debió enfrentarse con una otra realidad relegada, excluida y negada de aquel “mundo de la inmigración” que construyó en sus fotografías: la de los pueblos indígenas de la provincia. Conforme entonces a los intereses de sus demandantes del reportaje fotográfico -el Banco del Chaco- y sus propios preceptos de "lo fotografiable", Raota eligió suprimir del encuadre de sus

23 En otras imágenes fotográficas que no integran la serie que aquí nos ocupa, algunas de las cuales fueron tomadas en el ámbito de un estudio fotográfico y usadas en campañas gráficas solidarias, Raota registra a indígenas mediante ciertos atributos y accesorios propios de una vestimenta "típica", que pareciera connotar cierto "primitivismo". Por medio de algunos rasgos presentes sobre todo en los atuendos de los retratados, Raota parece apoyar una concepción dualista del pueblo chaqueño que divide entre indígenas e inmigrantes. Un ejemplo de ello es un portafolio de 1976 en el que representa a una mujer de torso desnudo con un niño en brazos, titulada Madre indígena. La desnudez es la encargada en esta oportunidad de trazar la diferencia y el contraste con el "mundo blanco". 
tomas todos aquellos indicios que remitieran explícita o implícitamente a la representación del indígena. ${ }^{24}$

La decisión de suprimir la representación del indígena de la toma fotográfica no solo alude a las percepciones, intereses y "motivos" propios del contexto de producción de estas imágenes, sino también enfatiza el hecho de que la elección de un aspecto determinado de lo real -en este caso los inmigrantes europeos en el Chaco-, configura "la actuación del fotógrafo como filtro cultural" (Kossoy 35).

Como expresamos, el ideal progresista subyace a la emotividad que produce su poética fotográfica y se vislumbra en valores como el trabajo, la salud, la educación, etcétera. Valores que se corresponden con la moral cristiana, la tradición nacional y la "dignidad del ser argentino", que actuaron como componentes del marco ideológico que guio las acciones del llamado "Proceso de Reorganización Nacional". ${ }^{25}$ Todas las imágenes sociales nos enfrentan con la ausencia de identificaciones personales y su reemplazo por títulos con esta unilateralidad ideológica. La casi totalidad de los mismos alude de manera explícita a la realidad del colono inmigrante y su aporte civilizatorio para con un Chaco "desierto" capaz de convertirse en la "tierra del porvenir”. En términos generales, estas imágenes focalizan en el imaginario del "progreso y civilización", es decir, en el extremo que se ha construido históricamente para conformar un imaginario uniforme de la representación del indígena chaqueño (Reyero).

Ello nos lleva discutir en qué medida las imágenes de Raota, al satisfacer una concepción de progreso del inmigrante chaqueño, delimitan la esfera de reconocimiento de la realidad social y cultural del Chaco. O dicho de otro modo, hasta qué punto -en términos de Sekula- "cuando observamos una fotografía nos enfrentamos a un doble sistema de representación capaz de funcionar a la vez como forma honorífica y represiva" (cit. en Batchen 57).

Todas las imágenes sociales de Raota de la serie Chaco siguen una política de omisión del indígena chaqueño. Esta intrascendencia visual se apoya en una visión etnocéntrica que concibe al indígena no solo como otro-diferente, sino como otroausente. Ese "otro" no pertenece al mundo moderno: "[...] se fue desdibujando el rostro del indio, simplemente por no ser 'moderno', por pertenecer a lo 'arcaico' o en todo caso al relicto de un 'pueblo atrasado e inculto"' (Baldasarre s. p.).

Por todo ello, la mirada que Raota arroja sobre la realidad chaqueña juega un rol decisivo en este proceso de homogeneización y políticas de construcción de memorias

24 En tal sentido, sorprende que en exposiciones recientes de esta serie en la ciudad de Buenos Aires (a las que nos referiremos más adelante), la prensa aluda al mundo indígena representado, cuando es prioritariamente inmigrante y criollo.

25 Entre los "principios y procedimientos" establecidos por la Junta Militar en 1976 y difundidos por los medios masivos de comunicación estaban aquellos referidos al futuro del país. Futuro que debía emerger de "la restitución de valores fundamentales que contribuyeran a la integridad de la sociedad, tales como: orden, trabajo, jerarquía, responsabilidad, identidad, honestidad, etc., en el contexto de la moral cristiana" (Simpson cit. en Veiravé s. p.). 
unívocas y definitivas que se continúan reproduciendo cada vez que las imágenes son expuestas -lo han hecho los sucesivos gobiernos democráticos- como "la imagen del Chaco". Lo diferente, lo múltiple, tanto como lo ambiguo y los deseos, también están ausentes en el mundo de este rostro del Chaco de 1978.

\section{El Estado presente y la refundación del Chaco}

El rol del Estado es un aspecto recurrente en la producción de Raota, que se evidencia en los títulos ilustrativos elegidos con la intención de enfatizar la claridad de lectura de la imagen y quitarle cualquier espesor de ambigüedad. De esta forma, contribuyen a la transmisión visual de una ideología vinculada a la "causa nacional" que el gobierno militar pretendía instaurar.

El Estado se hace presente en forma simbólica por medio de una narración aparentemente ingenua de la realidad, pero que encubre un mensaje ideológico preciso. Raota recurre a un juego dialéctico entre "carencias sociales" y "provisiones estatales". Tal es el caso de dos imágenes en las que se reflejan situaciones similares en dos momentos diferentes: una de ellas se titula Llegará la luz: la escena se compone con la presencia de una mujer y una niña -posiblemente una abuela y su nieta- leyendo bajo la luz de una farola a kerosén. La otra imagen, Y llegó la luz, muestra un grupo de niños reunidos en torno a un libro bajo un foco de luz eléctrica. El evidente contraste temporal se remarca en la conjugación futura del verbo del primer título (llegará), que sugiere cierta nota de esperanza o expectativa, y el pasado del segundo título (llegó) mediante el cual se alude a la idea de concreción lograda por la extensión de electrificación rural de pequeños poblados del interior chaqueño, acción que la política del Estado provincial mostraba como uno de los avances del "progreso" (fig. 5).

El antes y el después de la intervención del Estado queda así plasmado mediante una sugestiva interrelación y apoyo mutuo de palabra e imagen. Ambos títulos resultan no solo juicios de valor del propio fotógrafo, sino también pistas de lectura que orientan a un sentido unívoco por parte del espectador. Texto e imagen actúan como medio de propaganda de la acción estatal, apoyándose mutuamente en la argumentación discursiva.

De un modo más directo e ilustrativo, obras como Urgente, en la que se presenta una ambulancia en medio de un camino polvoriento del Chaco, unifica un título atractivo con una fácil lectura del tema: la salud está presente en todos los rincones del Chaco. La captación de esta toma aérea -uno de los recursos técnico-formales que se hace recurrente en los paisajes- es solo uno de los ejemplos que pretenden ilustrar la protección estatal de la salud, ya que otras imágenes la reflejan en interiores de centros de salud en Puesto sanitario, Sala de espera o El precio de la salud.

La educación estatal también se representa en composiciones de niños en el interior de las escuelas o en edificaciones escolares como el Colegio Nacional de Resistencia, que constituyó otro de los ejemplos de las construcciones oficiales de la época. Esta 
FIGURA 5

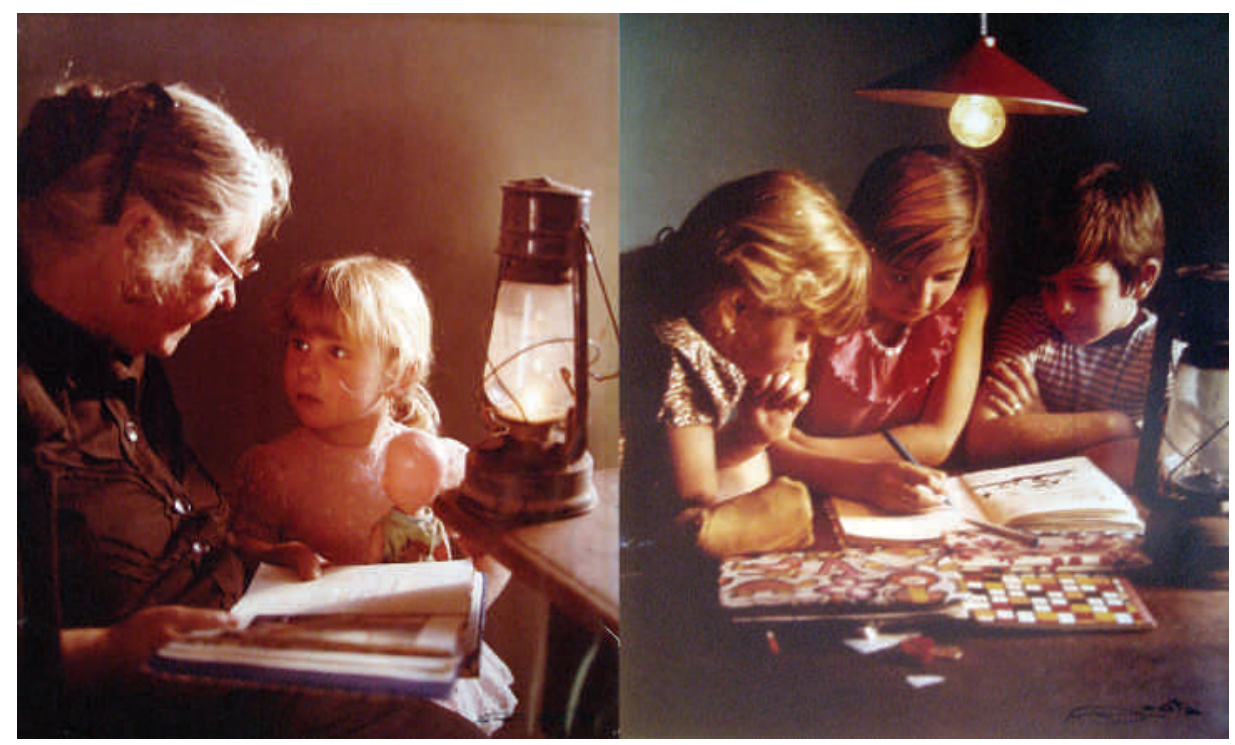

Pedro Luis Raota. Llegará la luz e Y llegó la luz (1978). Museo Provincial de Bellas Artes "René Brusau”.

edificación actúa de marco de una imagen titulada Recreo, en la que se advierte un grupo de niños jugando al fútbol en el patio delantero del colegio.

Enseñando a amar (fig. 6), también se inserta en esta línea: un grupo de niños formados para izar la bandera se hallan en el contexto de una pequeña escuela rural, donde Raota expone sus dotes técnicas en el manejo de la composición y el uso acentuado de la perspectiva en una toma aérea. Resulta interesante relacionar la fuerte carga semántica del título que asocia la educación escolar con uno de los sentimientos "puros" de la naturaleza humana: el amor vinculado al concepto de "patria" simbolizado por la bandera, tan utilizado en la estrategia comunicacional y propagandística del gobierno militar. "Juventud", "patria", "pureza", "autenticidad" eran conceptos reiterados en los discursos presidenciales. Decía el presidente de facto Videla, en su discurso del 30 de marzo de 1976:

Las Fuerzas Armadas sabemos que el esfuerzo que hoy realizamos todos, tiene un natural heredero: la juventud argentina.

A ella le ofrecemos la autenticidad de nuestros hechos, la pureza de nuestras intenciones, nuestro trabajo sin desmayos.

De ella reclamamos su fuerza creadora, sus patrióticos ideales, su sentido de responsabilidad en el claustro y en el taller, su participación en el proceso que se inicia, para que, en un marco de igualdad de oportunidades, se realice plenamente en beneficio exclusivo de la Patria (13).

Escuelita chaqueña es otra imagen por medio de la cual la educación se hace presente y en la que pareciéramos asistir a una escena espontánea, extraña en el conjunto de 


\section{FIGURA 6}

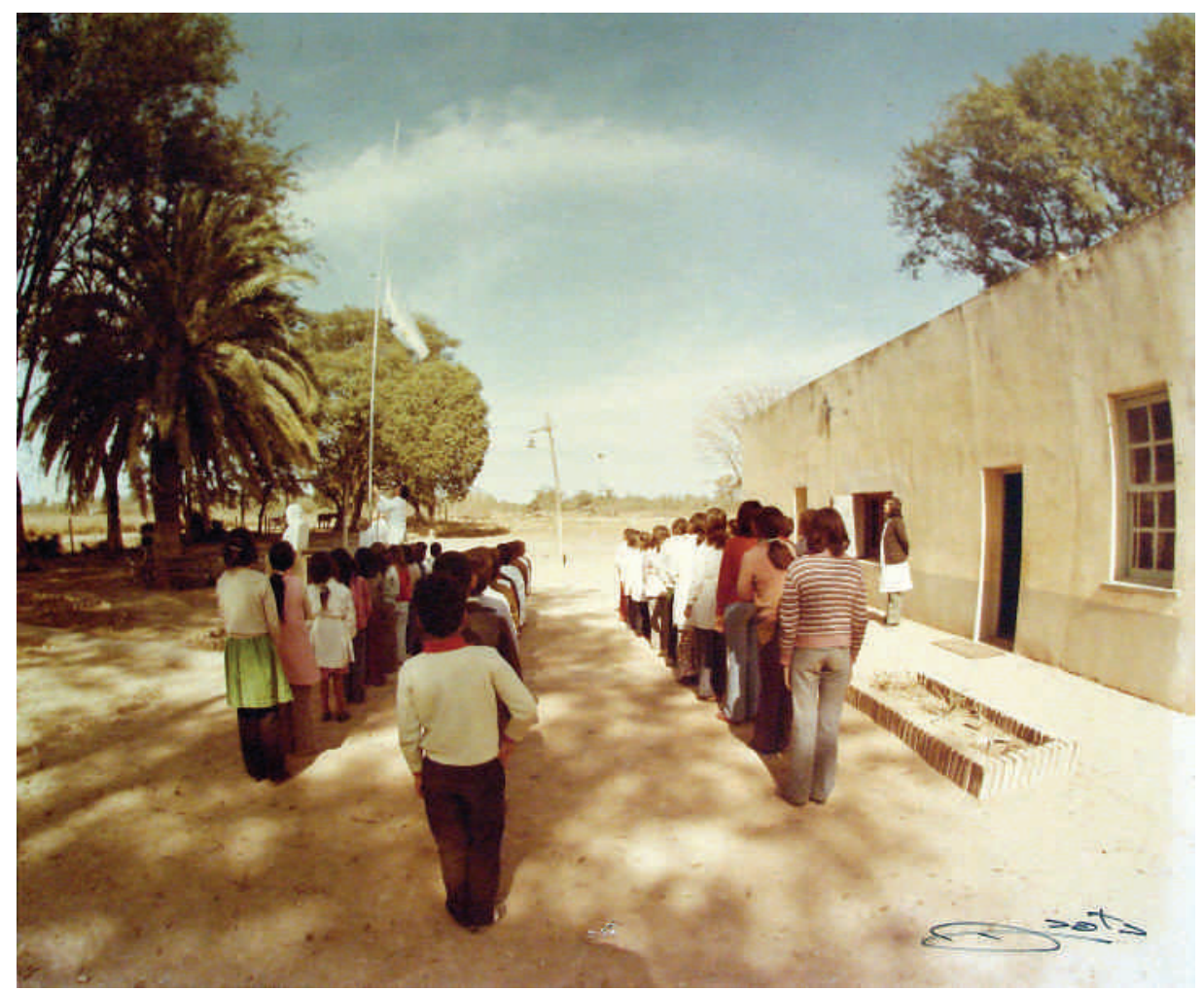

Pedro Luis Raota. Enseñando a amar (1978). Museo Provincial de Bellas Artes “René Brusau”.

la colección. Dos niños observan atentos el ángulo de la toma que probablemente corresponde al pizarrón del aula o a su maestro. Como en los otros casos, el título de esta foto cobra especial relevancia al remarcarse con el diminutivo de la primera palabra la idea de desamparo, soledad y aislamiento de una escuela posiblemente rural.

No son solo estas representaciones visuales, las escenas y los títulos de las fotografías las que sirven para acreditar el rol/función que el Estado asume en el contexto de la nueva nación, sino que la obra pública concretada busca operar como prueba del "progreso" delineado en la política estatal. Por ello, las edificaciones fueron sin duda uno de los objetos de representación sobresalientes dentro de la producción de Raota. Estas eran la concreción del modelo ideológico del gobierno. La edificación del Domo del Centenario y del moderno edificio del Banco del Chaco, en los inicios de su construcción, y el acueducto al interior de la provincia fueron -para Raota-focos de atención o señalamientos específicos de las autoridades que lo contrataron para simbolizar el Estado presente y la refundación del Chaco.

El símbolo del progreso material que se construye visualmente con la presencia del Estado, se afianza en imágenes que se basan en el "progreso social" del poblador 
que vive en estos espacios marginales del país: en Ayer y hoy un carro se contrapone visualmente a un automóvil último modelo en movimiento. Pasado y futuro se juegan en esta representación que construye un imaginario social. En esta misma línea, otras imágenes están dedicadas al avión del Banco del Chaco, comitente de esta producción; tomas que aluden al "rescate" que en lo económico y social simbolizaba la institución. Estas imágenes se corresponden con los discursos que presentaban a la entidad financiera como instrumento de salvamento social y no solo económico.

En otras representaciones del "progreso", se muestran obreros en bicicleta saliendo del ámbito de obras estatales en construcción (Chaco hoy) o retratos de algunos de ellos trabajando (El Nuevo Chaco), que explicitan la relación entre trabajo-construcción estatal, aludiendo a la nueva provincia que se pretende configurar.

El tópico del trabajo como símbolo de progreso también abarca la temática productiva en escenas que exhiben las actividades primarias que dan sustento a la economía chaqueña. La actividad forestal, el cultivo algodonero, el girasol, la actividad ganadera, el carbón, quedan perpetuados en imágenes como Gigante caído, El grito del quebracho, Quebracho, Tanino, Nieve chaqueña. En este "nuevo Chaco" también la industria se hace presente como símbolo del progreso: Algodón (fig. 7), una toma en escorzo en una hilandería, se presenta como el ejemplo de la posibilidad de procesar la materia prima local, en concordancia con el discurso oficial del desarrollo industrial de la época.

Tanto las imágenes que resaltan el rol del Estado como estas que articulan un "progreso material" con un "progreso social" -educación, infraestructura, actividad económica-, se entienden en el discurso de la refundación de un "nuevo Chaco", consecuente con el discurso nacional de una "refundación de la Nación” y que se sintetizaba en el eslogan político de la época, "Chaco puede": el elegido para una de las provincias con mayores índices de analfabetismo, pobreza y desigualdad del país.

\section{El paisaje como espacio posible}

El paisaje, que ha sido prioritariamente un tópico de representación identitaria en el arte chaqueño (Giordano y Reyero), fue también capturado por la lente de Raota. En cada una de las tomas, el paisaje no solo aparece en su mera dimensión territorial, sino también como un acto de observación; es una mirada que construye el espacio de lo potencial, de lo posible. Frente a la diversidad natural chaqueña, Raota decide eternizar aquellos aspectos/lugares que den cuenta explícitamente de un imaginario homogéneo de provincia.

Podemos identificar dos grandes núcleos visuales en los cuales el paisaje aparece como protagonista: el paisaje natural y el pasaje construido. En cuanto al primero se suceden tomas del monte, la influencia del sol sobre la tierra (im)productiva -por la sequía- y en una escala micro, la centralidad que asume el quebracho como árbol arquetípico de la región, pero también como estereotipo visual del Chaco, asocia- 


\section{FIGURA 7}

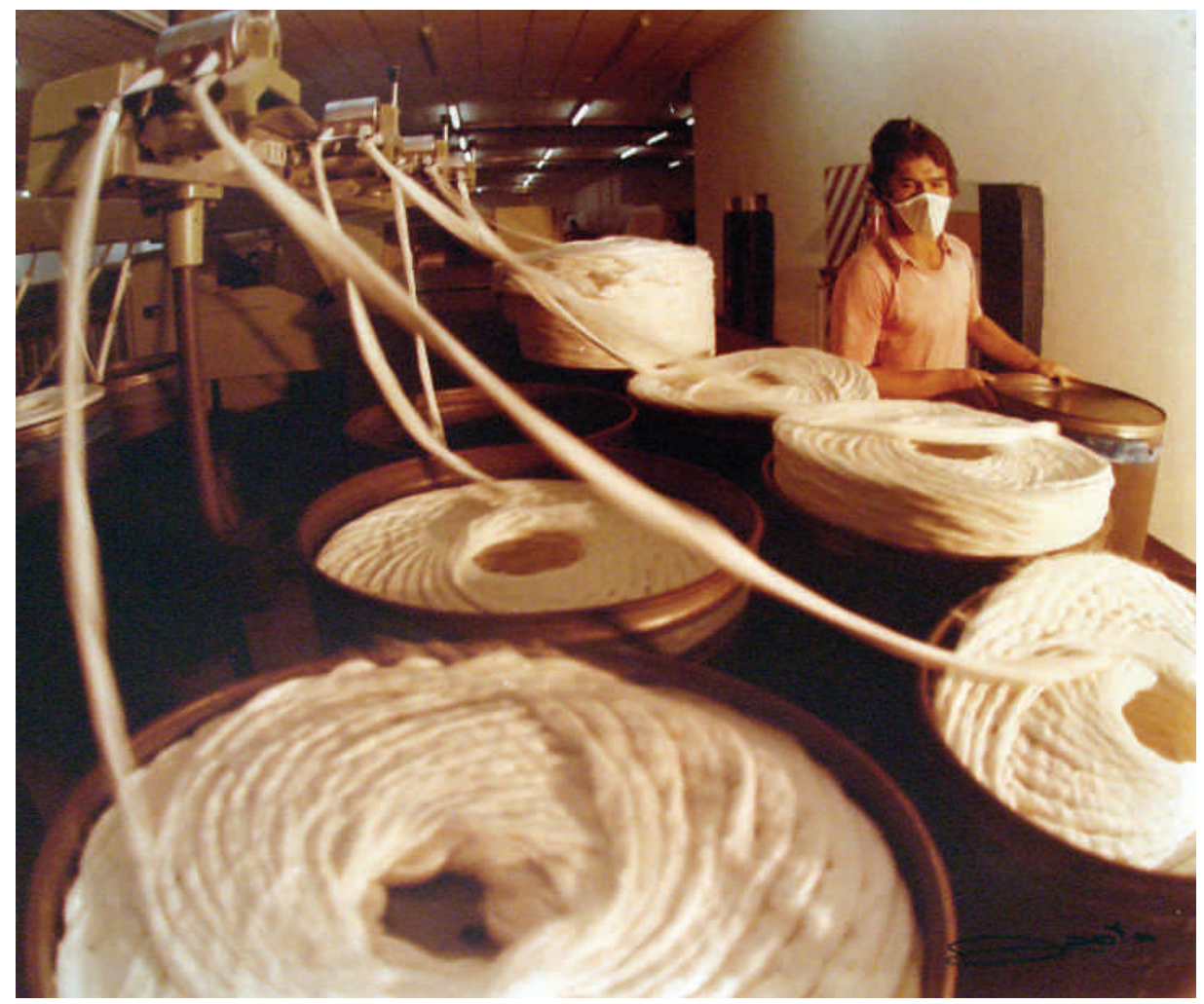

Pedro Luis Raota. Algodón (1978). Museo Provincial de Bellas Artes “René Brusau”.

do a la histórica actividad forestal de la región. Estas imágenes expresan un modo tradicional de toma fotográfica basada en un cuidadoso equilibrio compositivo. En el caso de la fotografía Sol y quebracho, ambos elementos se conjugan en el centro de la toma estructurando radialmente la escena. Asimismo, la intersección captada entre el sol y el quebracho se enfatiza con la presencia de diagonales (rayos solares y ramas) logrando un profundo punto de atracción óptica en el centro de la foto. Ello se enriquece con un juego de luz que funde el fondo con el primer plano, a la vez de otorgarle dinamismo a la escena.

En Nuestra agua (fig. 8), Raota adhiere a una representación estereotipada del imaginario relativo al paisaje chaqueño: el río y las frondosas riveras. La presencia humana se expone en el centro de la escena con la figura de un canoero. La sugerente calma lograda en este registro, la manera en que el personaje se incorpora a la imagen formando parte del ambiente ribereño, produce la exaltación del paisaje natural, construyendo otra estampa chaqueña. Aun cuando la imagen pudiera parecer una toma instantánea, es una composición construida por el autor. El paseo 


\section{FIGURA 8}

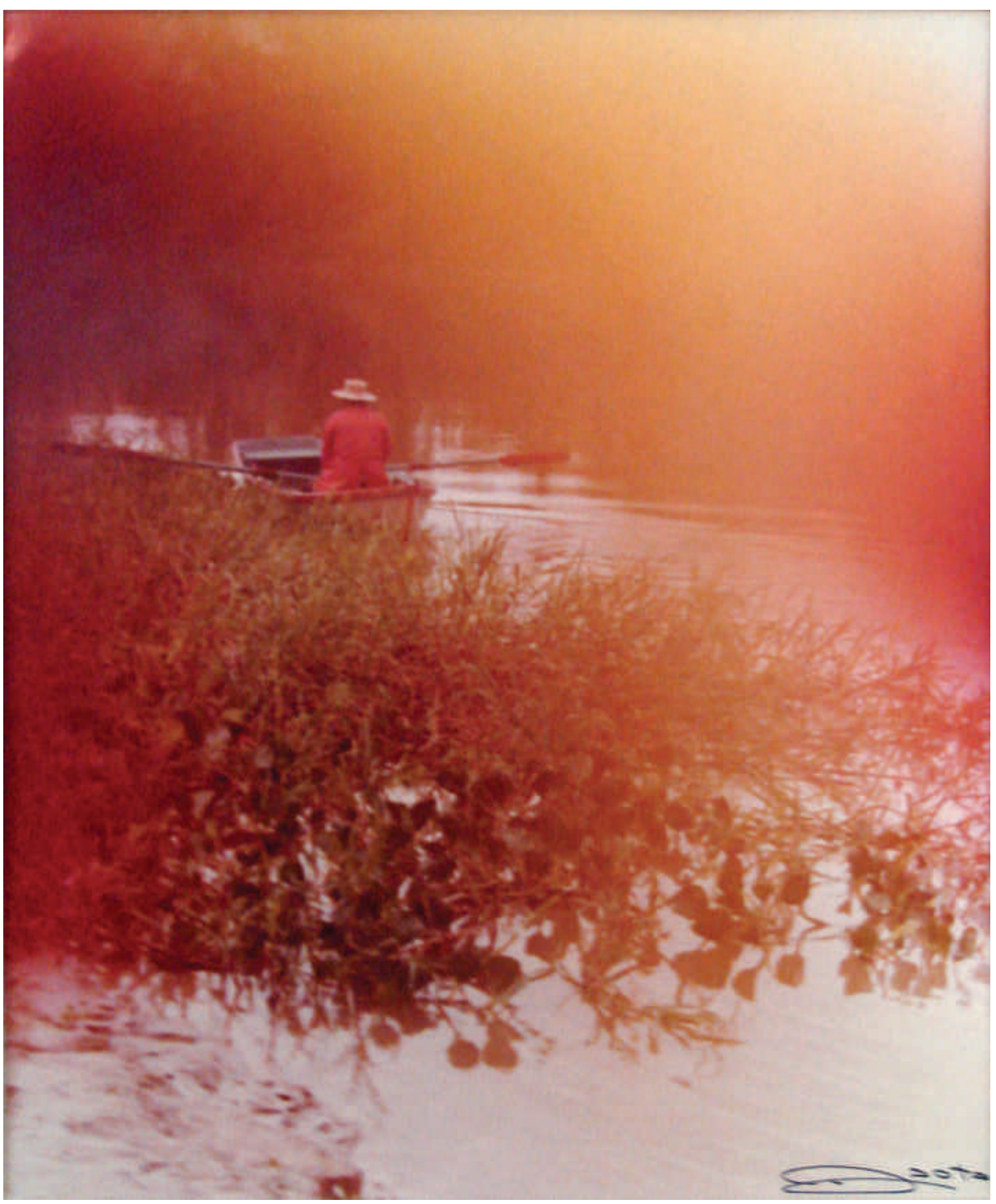

Pedro Luis Raota. Nuestra agua (1978). Museo Provincial de Bellas Artes “René Brusau”.

plácido del canoero no es inocente ni casual, sino que responde a una puesta en escena del fotógrafo: el personaje aludido es uno de los empleados del banco que acompañó a Raota en el recorrido de su reportaje fotográfico. ${ }^{26}$ 
Como hemos expuesto, dentro del género de paisaje que aborda Raota existen otras fotografías en que la acción del hombre chaqueño sobre el paisaje natural adquiere protagonismo: Mecanizándose y Quemando rastrojos son dos fotografías en que claramente se evidencia una concepción positivista respecto a la relación hombre y medio ambiente, hombre y paisaje. En ambas el sujeto aparece en su rol indiscutible de "dominador de la naturaleza", pero la máquina simboliza el progreso que sustenta el discurso visual de Raota y el propagandístico del régimen militar.

También presenta al campesino y su poder transformador de una tierra potencialmente productiva: el trabajo agrario se exalta no solo como acto de supervivencia, sino como hacedor de la soberanía nacional. De este modo, la escena rural de la gringa y su rebaño, o de hombres arriando el ganado, remiten a un Chaco rural y productor, reivindicando la labor del chacarero y las bonanzas de la producción agrícola ganadera. Así se construyó la patria, una de las imágenes obtenidas desde el avión, revela en su título este concepto, a la vez que el referente nos muestra un hombre trabajando la tierra con un arado tirado por dos caballos.

En contraposición a estas imágenes, la fotografía Seco, seco, seco deja ver otra realidad del interior chaqueño: el interior occidental. Se compone con el retrato de dos niños descalzos en cuclillas con un pequeño becerro, sobre un suelo estéril, resquebrajado por la falta de agua. En el contexto de la serie esta imagen sugiere una carencia en determinados ámbitos del territorio, que se complementa una vez más con la intervención del Estado como agente de bienestar en la obra antes mencionada, Acueducto.

\section{¿Elogio estético y descalificación política? Algunas conclusiones}

¿Cómo logró Raota obtener sus imágenes en medio de un contexto de conflicto social, de represión, de censura, cuando la misma creación artística estaba limitada?

Raota presenta una poética consecuente con los presupuestos del régimen militar: construye una realidad visual por medio de ciertos índices que reorganizan lo visto y lo introducen en una trama de significados que, junto a los títulos, enfatizan el imaginario del "Chaco puede".

La politicidad de la imagen adquiere aquí un rol significativo: su estética documental-poética no busca confrontar miradas, sino, por el contrario, ser condescendiente con la mirada política del momento, a la vez que catalizadora de esperanzas de una región marginal de la Argentina.

Es por ello que, cuando esta serie circuló en la primera exposición realizada en el Chaco en el mismo año 1978, las imágenes fueron recibidas con aceptación, como lo siguen siendo cuando se exponen en diversos espacios del Chaco. Han pasado a conformar una memoria social local porque sistemáticamente el Estado 
ha reactualizado en otros contextos históricos estas imágenes como símbolos de la provincia, aun en periodos de gobiernos democráticos de diferentes signos políticos. ${ }^{27}$

Todo ello puede llevarnos a preguntar ¿cómo separar esa politicidad y uso propagandístico de la imagen de la esfera estrictamente estética? ¿Cómo deslindar las cuestiones contextuales de las meramente formales y técnicas que también conforman la representación fotográfica?

Es tal vez en este sentido que -tomando una idea de García Canclini- la obra fotográfica de Raota es digna de elogio estético y a la vez de descalificación política, ya que la búsqueda y elección de una imagen es siempre ideológica. Resulta relevante reflexionar no solo sobre lo que Raota decide fotografiar, lo que prefiere registrar y privilegiar, sino qué ideología subyace a tales "privilegios visuales": lo ideológico remite -siguiendo a García Canclini (18) - no solo al campo de las ideas y las imágenes, sino también y especialmente al proceso de producción social que tiene sus bases materiales y supone relaciones sociales y medios físicos -aparatos o instituciones- precisos.

En consecuencia, se puede afirmar que la ideología de la dictadura militar argentina de la década del setenta necesitaba también de una expresión visual que la hiciera posible, le diera unidad y la mostrara como coherente y estable. Las imágenes de Raota contribuyeron a este fin, no solo porque hicieron visible el conjunto de ideas e ideales promulgados, sino también porque fueron el resultado de un aparato institucional estatal que actuó de comitente -el Banco del Chaco- y de las relaciones, los acuerdos y los convenios entablados entre este y el fotógrafo. Fue desde este campo de relaciones sociales e institucionales desde donde y para el cual se generaron las fotografías, con la probable intención de alcanzar una amplia difusión social en tanto "íconos" del progreso dignos de ser vistos por toda la sociedad en el marco de una estrategia aleccionadora de conducción política.

Es entonces el tejido de estas relaciones sociales, políticas y culturales el que vuelve inteligible de modo crítico y "responsable" cada una de las imágenes fotográficas de la serie Chaco 1978. En tal sentido, no podemos dejar de advertir que la producción fotográfica de Raota jugó un rol sobresaliente en la formación de una imagen nacional para el país y el mundo en la década del setenta, dando cuenta de su poder cultural para transformarse en un medio de "propaganda ideológica” (Pérez Fernández 47).

En este proceso de construcción de relatos, identidades y memorias, se pretendió transmitir una única imagen compacta, homogénea, sin fisuras del "Chaco puede", y los intereses, los recortes, las manipulaciones, las omisiones no fueron meras estrategias compositivas, sino claramente ideológicas.

27 Una exposición que la Casa del Chaco en Buenos Aires realizó sobre Raota con estas y otras imágenes en el marco de un "Homenaje a los Maestros" del arte chaqueño, lo presentaba como el "artista que a través de su cámara puso el nombre de la provincia en varias partes del mundo", mostrando en sus imágenes "la herencia de los pueblos originarios y el aporte inmigratorio, su desarrollo y el despegue de una región que pese a las inclemencias y dificultades se construyó así misma con la fuerza de sus hombres". Diario Chaco, 1 mayo 2013. 
Siguiendo a Ricoeur:

[...] fue posible la ideologización de la memoria gracias a los recursos de variación que ofrece el trabajo de configuración narrativa. Las estrategias del olvido se injertan directamente en ese trabajo de configuración: siempre se puede narrar de otro modo suprimiendo, desplazando los momentos de énfasis, refigurando de modo diferente a los protagonistas de la acción al mismo tiempo que los contornos de la misma (572).

\section{Referencias}

Baldasarre, Carlos. "La aculturación de Ángela Loij a través de su imagen fotográfica”. Revista Chilena de Antropología Visual, n. ${ }^{\circ}$ 10, 2007, http://www.rchav. cl/2007_10_art05_baldassarre.html.

Batchen, Geoffrey. Arder en deseos. La concepción de la fotografía. Trad. Antonio Fernández Lera. Barcelona, Gustavo Gilli, 2004.

Blejmar, Jordana, Natalia Fortuny y Luis Ignacio García, editores. Instantáneas de la memoria. Fotografía y dictadura en Argentina y América Latina. Buenos Aires, Libraria, 2013.

Borelli, Marcelo y Jorge Saborido. “La prensa del 'Proceso'. El diario Convicción durante la dictadura militar argentina (1976-1983)”. Estudios sobre el Mensaje Periodístico, n. ${ }^{\circ}$ 14, 2008, http://revistas.ucm.es/index.php/ESMP/article/view/ ESMP0808110049A.

Burgin, Victor. "Something about Photography Theory". Screen 25, n. ${ }^{\circ}$ 1, 1984, pp. 61-66.

Burke, Peter. Visto y no visto. El uso de la imagen como documento histórico. Trad. Teófilo de Lozoya. Barcelona, Crítica, 2001.

Carlino, Alicia. Economía Provincial y financiamiento público. El Banco de la Provincia del Chaco (1956-1983). Buenos Aires, Ediciones Cooperativas, 2008.

Da Silva Catela, Ludmila. "Hacer visible lo clandestino. Fotografía y video frente a la experiencia concentracionaria". Fotografía e identidad. Captura por la cámara, devolución por la memoria. Eds. Ludmila Da Silva, Mariana Giordano y Elizabeth Jelin. Buenos Aires, Nueva Trilce, 2010, pp. 85-103.

Diario El Territorio [Resistencia, Chaco], 23 sept. 1978, p. 2.

"El fotógrafo chaqueño Luis Raota expone en Buenos Aires". Diario Chaco, $1^{\circ}$ mayo 2013. http://www.diariochaco.com/noticia/174542/El-fotografo-chaquenoLuis-Raota-expone-en-Buenos-Aires.html. Visitado 23 de mayo de 2019.

Facio, Sara. La fotografía en la Argentina. Desde 1840 a nuestros días. Buenos Aires, La Azotea, 1988.

Feld, Claudia. "Imagen, memoria y desaparición. Una reflexión sobre los diversos soportes audiovisuales de la memoria”. Aletheia vol. 1, n. ${ }^{\circ}$ 1, 2010, http://www. aletheia.fahce.unlp.edu.ar/numeros/numero-1/pdfs/Feld-\%20Aletheia\%20 Vol\%201.N1.pdf 
Franco, Marina y Florencia Levín, compiladoras. La historia reciente en Argentina. Perspectivas y desafíos. Buenos Aires, Paidós, 2007.

Gamarnik, Cora. "Imágenes de la dictadura militar. La fotografía de prensa antes, durante y después del golpe de Estado de 1976 en Argentina”. Artículos de investigación sobre fotografía. Eds. Silvia Pérez Fernández y Cora Gamarnik. Montevideo, Ediciones CMDF, 2011, pp. 49-80.

---. "La fotografía irónica durante la dictadura militar argentina: un arma contra el poder”. Discursos fotográficos, Londrina, v. 9, n. ${ }^{\circ}$ 14, jan. / jun. 2013, pp.173-197.

---. “Imágenes de la postdictadura en Argentina”. Artelogie, n. ${ }^{\circ}$ 7, 2015, http://cral. in2p3.fr/artelogie/spip.php?article34

García Canclini, Néstor. “Fotografía e ideología”. Segundo Coloquio Latinoamericano de Fotografía Hecho en Latinoamérica. México, D. F., Consejo Mexicano de Fotografía, 1981, pp. 19-20.

Giordano, Mariana y Luciana Sudar Klappenbach, coordinadoras. Fotografía chaqueña. Puesta en valor y análisis de las colecciones Simoni, Boschetti y Raota. Buenos Aires, Consejo Federal de Inversiones, 2012.

Giordano, Mariana y Alejandra Reyero. "El paisaje como política y su potencialidad temporal". Temas de la Academia Nacional de Bellas Artes: El paisaje como otra naturaleza. Buenos Aires, Academia Nacional de Bellas Artes, 2016, pp. 20-30.

Geraldi, Seferino. Los que poblaron la Sección Resistencia. Resistencia, s. e., 1979.

Halbwachs, Maurice. La memoria colectiva. Trad. Inés Sancho-Arroyo. Zaragoza, Prensas Universitarias de Zaragoza, 2004.

INDEC. “Tasa de mortalidad infantil por mil nacidos vivos, según provincia de residencia de la madre. Total del país. Años 1980-2011”. Buenos Aires, Dirección Nacional de Estadística y Censos, https://www.indec.gov.ar/ftp//nuevaweb/ cuadros/7/sesd_04b01.xls, 2017.

---. Censo Nacional de Población y Vivienda 1980. Provincia del Chaco. Buenos Aires, Instituto Nacional de Estadística y Censos, 1981.

Jelin, Elizabeth. Los trabajos de la memoria. Madrid, Siglo XXI, 2002.

Jensen, Silvina y Gabriela Águila. "Interrogar el pasado reciente más allá de las fronteras nacionales: entre lo local, lo trasnacional y las perspectivas comparadas". Clepsidra. Revista Interdisciplinaria de Estudios sobre Memoria, n. ${ }^{\circ} 4,2017$, http://ppct.caicyt.gov.ar/index.php/clepsidra/article/view/Introducci\%C3\%B3n.

Kossoy, Boris. Fotografía e historia. Trad. Paula Sibila. Buenos Aires, La Marca, 2000. Larralde Armas, Florencia. "Memorias sobrevivientes: el álbum familiar en tres obras artísticas sobre la desaparición (Marcelo Brodsky, Gerardo Dell'Oro, Lucila Quieto)". Amérique Latine Histoire et Mémoire. Les Cahiers ALHIM, n. 30, 2015, http://journals.openedition.org/alhim/5374.

Leconte, Mariana. "Fos, grafé, logos. Imágenes, memoria e identidad narrativa”. Identidades en foco. Fotografía e investigación social. Comps. Alejandra Reyero y Mariana Giordano. Resistencia, IIGHI-CONICET/UNNE- Facultad de Artes, Diseño y Ciencias de la Cultura - UNNE, 2011, pp. 27-38. 
Leoni, María Silvia. "Resistencia: cómo se escribió la historia de la ciudad”. Nordeste n. ${ }^{\circ}$ 9, 1998, pp. 157-173.

Longoni, Ana. "Prólogo". Instantáneas de la memoria. Fotografía y dictadura en Argentina y América Latina. Eds. Jordana Blejmar, Natalia Fortuny y Luis Ignacio García. Buenos Aires, Libraria, 2013, pp. 7-8.

Lorenzano, Sandra y Ralph Buchenhorst, editores. Políticas de la memoria. Tensiones en la palabra y la imagen. Buenos Aires, Gorla, 2007.

Mitchell, W. J. T. “Mostrando el ver. Una crítica de la cultura visual”. Estudios Visuales, n. ${ }^{\circ} 1,2003$, http://estudiosvisuales.net/.

Pérez Fernández, Silvia. "Fin de la Dictadura, inicio de disyuntivas: La fotografía argentina frente a la recuperación de la vida constitucional." Ojos crueles, n. ${ }^{\circ}$ 3, 2006, pp. 47-64.

Poggio, Anabella Laura. "La propaganda oficial de la última dictadura militar argentina (1976-1983): un análisis de sus imágenes y sus argumentos”. VI Congreso Internacional de Letras "Transformaciones culturales. Debates de la teoría, la crítica y la lingüística. Buenos Aires, UBA, 2014, http://cil.filo.uba.ar/sites/cil. filo.uba.ar/files/u1220/POGGIO_ACTAS_2014e.pdf.

Raota, Pedro Luis. Pedro Luis Raota - catálogo. Buenos Aires, Olympia Ediciones, 1976.

Reyero, Alejandra. "Entre el reconocimiento, la impugnación y la negación visual. La ausencia del indígena chaqueño en la fotografía de Pedro Luis Raota”. XXVIII Encuentro de Geohistoria Regional. Resistencia, Instituto de Investigaciones Geohistóricas, 2009, pp. 680-686.

Ricoeur, Paul. La memoria, la historia, el olvido. Trad. Agustín Neira. Buenos Aires, Fondo de Cultura Económica, 2004.

Saborido, Jorge y Marcelo Borelli. Voces y silencios: La prensa argentina y la dictadura militar (1976-1983). Buenos Aires, EUDEBA, 2011.

Sekula, Allan. "Desmantelar la modernidad, reinventar el documental. Notas sobre la política de la representación”. Efecto Real. Debates posmodernos sobre fotografía. Coord. Jorge Ribalta. Barcelona, Gustavo Gili, 2004, pp. 35-63.

Tagg, John. El peso de la representación. Trad. Antonio Fernández Lera. Barcelona, Gustavo Gili, 2005.

Triquell, Agustina. "Otras siluetas. Conmemoraciones virtuales de la última dictadura”. Versión. Estudios de Comunicación y Política, n. ${ }^{\circ}$ 32, 2013, http://bidi.xoc.uam. $\mathrm{mx} /$ MostrarPDF.php.

Videla, Jorge Rafael. "Discurso dirigido al Pueblo Argentino el día 24 de mayo de 1976 por el Excelentísimo Señor Presidente de la Nación el teniente general Jorge Rafael Videla, refiriéndose al Proceso de Reorganización Nacional, al cumplirse dos meses de iniciado el mismo". Discursos y Mensajes del Presidente de la Nación. República Argentina. Buenos Aires, Presidencia de la Nación, 1976, pp. 31-47. 
---. "Discurso pronunciado al asumir la Primera Magistratura de la República Argentina, exponiendo al Pueblo de la Nación los fundamentos del Proceso de Reorganización Nacional emprendido el 24 de marzo de 1976". Discursos y Mensajes del Presidente de la Nación. República Argentina. Buenos Aires, Presidencia de la Nación, 1976, pp. 7-15.

Veiravé, Federico Alfredo. "Ideología del terrorismo de Estado en Argentina: un análisis del elemento religioso". Tesis para optar al grado de Magister of Arts, Ohio University, 1995.

Enviado: 16 agosto 2017 Aceptado: 17 septiembre 2018 